\title{
Cost efficiency assessment of automated quality control of precast structures
}

\author{
Liudmila Kaverzina ${ }^{1, *}$, Galina Kovalenko ${ }^{1}$, Irina Dudina ${ }^{1}$, and Oleg Belskii ${ }^{1}$ \\ ${ }^{1}$ Bratsk State University, 665709 Bratsk, Russia
}

\begin{abstract}
Relevance of the research is conditioned by the necessity to enhance the factory quality control of reinforced concrete structures based on integral assessment of their reliability. The current system of selective quality control of precast concrete structures does not provide reliability assurance of the whole lot of products. The present research aims to develop operational procedure and consider economic feasibility of automated quality control of precast RC structures. Quality control is performed each shift according to the developed software system based on probabilistic methods considering statistic variability of the controlled parameters. The critical criterion of operational integrity of structures is integral assessment of the reliability indicators. The following theoretical research methods were used in the study: probabilistic-statistical, methods of system and economic analysis. Validity of the obtained results and economic feasibility were proved by experimental studies including fullscale tests.
\end{abstract}

\section{Introduction}

Serious attention has always been paid to the issue of operational integrity assessment of building structures and enhancement of their quality [1-7]. This objective is especially relevant during implementation of quality control of precast reinforced concrete (RC) structures $[1,2,8-14]$, which comprise the basis of modern construction in Russia due to complexity of climatic conditions. Production of precast RC structures requires providing the basic condition of their reliability at minimum expenses. The relevance of this engineering and economic problem is motivated by the necessity to enhance the system of in-process control and quality control of the output products to ensure that they are up to the required consumer properties $[1,2]$.

Currently, reinforced concrete factories perform operational integrity assessment of the output products in several stages as specified by the acting standard. First, current control of the separate quality indicators is performed (strength and deformation material properties, data on geometrical parameters and reinforcement). The stage of end products acceptance includes periodic proof tests of full-scale structures using strength load up to structural failure $[8,15]$. As described in $[1,2,11]$ the current system of selective factory control apart from economic inefficiency also almost does not consider process variability of each exact production and does not provide quality and reliability assurance of all the

\footnotetext{
*Corresponding author: Dekanfps@mail.ru
} 
structures from the test batch. The necessity of transition from selective to full factory control was stated in the research of V.V. Sudakov, E.A. Sekhniashvili, G.V. Slyusarev, V.I. Korobko, etc. $[9,10,12,13]$. The most rational and accurate solution of this objective could be implementation of integral reliability assessment of RC structures resulting from current control of certain parameters $[1,2,11,14]$. Along with that, it should be noted that current control at RC factories is conducted every shift and expenses for it are much lower than those for proof tests of the structures themselves [16].

So, the objective of integral reliability assessment of precast RC structures based on using probabilistic calculation methods gains its research relevance. Developed software system based on probabilistic algorithms enables to generalize and take into account the influence of variability of process factors and the controlled parameters on the consumer properties of output products on a shift basis $[2,14,17]$. The present study aims to develop methodology and prove economic feasibility of automated quality control of precast RC structures at the production stage.

\section{Materials and methods}

During solving the objectives set in the research probabilistic-statistical methods were used [1,2, 7, 18-27], methods of system and economic analysis [16], as well as experimental methods pertaining to testing of full-scale structures $[8,14,15]$.

Relying on the analysis of development and enhancement of probabilistic methods of building structures calculation, studies of the following Russian and foreign scientists were distinguished: V.D. Raizer, A.G. Tamrazjan, M.B. Krakovskiy, V.P. Chirkov, G. Augusti, A. Baratta, F. Casciati, G. Spaethe, etc. [1-3, 20-25]. To assess reliability of RC structures probabilistic methods were used, as described in [1-3, 14, 18, 21-23, 26]: method of statistical testing; statistical modeling; linear approximation of functions.

Following from analysis in the works $[1,2,14,18]$ the following condition serves as the basic criterion of operational integrity control of load bearing RC structures:

$$
\mathrm{R} \geq\left[\mathrm{R}_{\mathrm{i}}\right]
$$

where $R$ - actual reliability indicator, obtained from probabilistic calculations $[1,2,14,18]$;

$\left[R_{i}\right]$ - standard value of reliability indicator, accepted in accordance with the considered limit state $[1,2]$.

Based on the chosen probabilistic methods software system for reliability assessment of the basic load bearing RC structures was developed (roof and floor slabs, cross-beams, beams, trusses, wall panels, columns).

While developing methodology and operational procedure of automated shift-based quality control of structures based on integral assessment of their reliability, results of experimental studies of concrete samples, reinforcement and the structures themselves were used. Testing was conducted at the test room of "Bratskzhelezobeton" integrated plant (Russia). Operational procedure of automated non-destructive testing of operational integrity of RC structures is described in application for an invention [17], flow chart presenting the algorithm of this control method is given in Figure 1. 


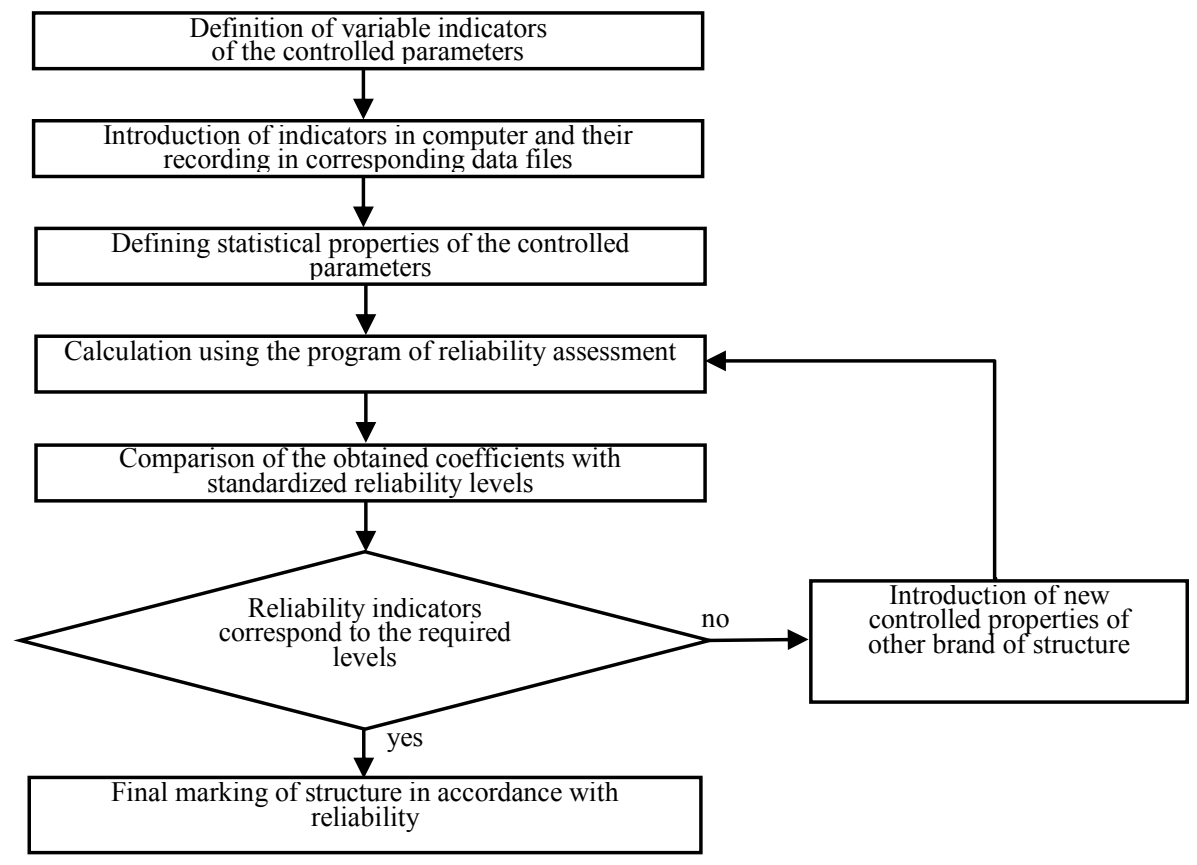

Fig. 1. Algorithm of automated shift-based reliability assessment of RC structures at the production stage.

Suggested non-destructive quality control of RC structures at the production stage begins with introduction of indicators of controlled parameters which are recorded into the corresponding data files after each shift $[14,18]$. Statistical processing of initial data is performed on the basis of small sample obtained during every shift and general total of testing results obtained considering a priory information per definite period of observation $[11,14]$. Further step is performing calculation with the basic software system for structural reliability assessment taking into account the worst statistical properties of controlled parameters. The obtained reliability indicators form the basis for final acceptance of the given lot of products and their certification according to requirements of strength, rigidity and crack resistance $[2,17,19]$. Structures are admitted as corresponding to the designed brand when following the condition (1). Final acceptance of structures is performed after their reliability assessment also considering check of flatness, diagonality and other parameters [8].

Checking the accuracy of operational procedure of the output products automated quality control requires conducting proof tests by strength loading at least once in 6 months [2, 17]. These tests can be replaced with effective methods of non-destructive testing $[12,13]$. In case the results of proof tests are lower compared to the probability assessment of structural reliability the reasons of this noncompliance are revealed and the actual load which shift products can sustain is defined [2].

Automated shift-based assessment of operational integrity is especially relevant when it concerns structures with complex stress state $[14,28]$. This refers to wall panels operating under biaxial bending and eccentric-compressed columns. Field tests of such structures (especially columns) in factory conditions are quite hard to implement. 


\section{Results}

The suggested automated non-destructive quality control provides opportunity for RC factories to manufacture structures with the required reliability level. Inclusion of computer system into workflow contributes to solving the objectives of operational stability assessment and defining reserves to reduce material consumption $[2,11]$. The options of structural optimization by reduction of their material consumption are implemented according to the developed software system taking into account variability of the calculated parameters and comparative economics [14, 16, 19].

Economic efficiency of the developed acceptance quality control of structures is defined by sharp decrease of the number of field tests (by 6-10 times). Following from the analysis of economic feasibility of implementing non-destructive testing for ribbed floor and roof slabs at "Bratskzhelezobeton" integrated plant, the output products showed production costs reduction by $2.4 \%$ [2]. The efficiency of the suggested automated non-destructive quality control for the basic list of precast structures is given in Table 1. Annual expenses for production and testing of the given structures according to Russian State Standard GOST 8829-94 and by automated method at "Bratskzhelezobeton" integrated plant are two-yearold prices.

Economic effect in this case will be formed due to cost reduction and can be defined the following way:

$$
\mathrm{E}=\mathrm{C}_{1}-\mathrm{C}_{2},
$$

where $C_{1}$ - expenses for conducting testing of structures in accordance with Russian State Standard GOST 8829-94 considering their production;

$C_{2}$ - expenses for production of RC structures and conducting testing using automated reliability assessment.

When the corresponding values from Table 1 are put into Formula (2), the economic effect is obtained, which is equal to 4069.05 thousand rubles. (4800.87-731.82).

Costs reduction due to implementation of automated quality control of RC structures under study is 6.7 times. Generally, implementation of the suggested shift-based nondestructive quality control of precast building structures allows improving performance indicators of construction industry enterprises which is shown on the case of "Bratskzhelezobeton" integrated plant (Table 2).

Table 1. Annual expenses for production and testing of different types of structures according to GOST 8829-94 requirements and by automated method.

\begin{tabular}{|c|c|c|c|c|c|c|c|c|}
\hline \multirow[b]{2}{*}{ 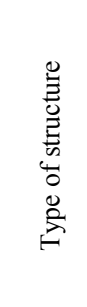 } & \multirow{2}{*}{ 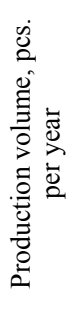 } & \multirow{2}{*}{ 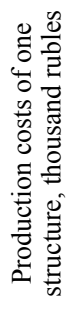 } & \multirow{2}{*}{ 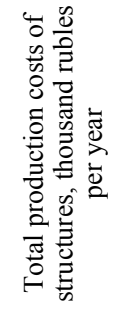 } & \multirow{2}{*}{ 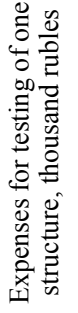 } & \multicolumn{2}{|c|}{$\begin{array}{l}\text { Testing according to } \\
\text { GOST 8829-94 }\end{array}$} & \multicolumn{2}{|c|}{ By suggested method } \\
\hline & & & & & 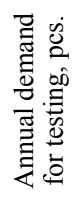 & 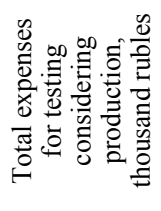 & 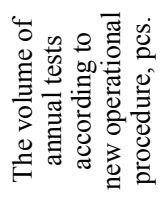 & 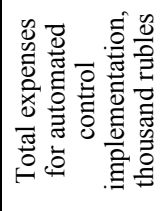 \\
\hline Truss & 124 & 27.24 & 3377.64 & 22.95 & 4 & 200.76 & 2 & 120.46 \\
\hline Beam & 286 & 24.96 & 7137.70 & 17.01 & 8 & 335.76 & 2 & 125.90 \\
\hline $\begin{array}{l}\text { Cross- } \\
\text { beam }\end{array}$ & 420 & 18.37 & 7715.82 & 14.27 & 36 & 1174.97 & 4 & 195.83 \\
\hline $\begin{array}{l}\text { Wall } \\
\text { panel }\end{array}$ & 6800 & 16.70 & 113587.2 & 15.48 & 96 & 3089.38 & 6 & 289.63 \\
\hline Total & 7630 & - & 131818.36 & - & 144 & 4800.87 & 14 & 731.82 \\
\hline
\end{tabular}


Table 2. Variability of performance indicators of enterprise by using automated quality control of building structures.

\begin{tabular}{|c|c|c|c|c|c|c|c|}
\hline \multirow{4}{*}{ 总 } & \multirow{4}{*}{ 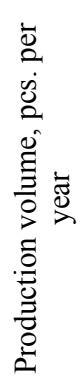 } & \multirow{4}{*}{ 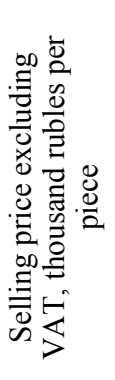 } & \multicolumn{5}{|c|}{ Indicators by different control ways } \\
\hline & & & \multicolumn{5}{|c|}{ Testing acc. to GOST 8829-94 } \\
\hline & & & \multicolumn{5}{|c|}{ By suggested method } \\
\hline & & & 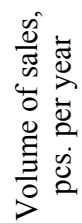 & 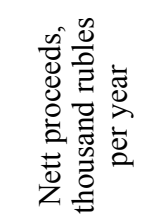 & 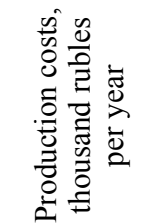 & 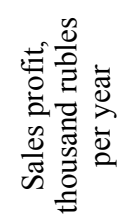 & 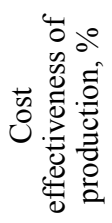 \\
\hline Truss & 124 & 31.33 & $\frac{120}{122}$ & $\frac{3759.6}{3822.26}$ & $\frac{3469.40}{3443.62}$ & $\frac{290.20}{378.64}$ & $\frac{8.36}{11.00}$ \\
\hline Beam & 286 & 28.90 & $\frac{278}{284}$ & $\frac{8034.2}{8207.6}$ & $\frac{7273.70}{7213.69}$ & $\frac{760.50}{993.91}$ & $\frac{10.46}{13.78}$ \\
\hline Cross-beam & 420 & 21.68 & $\frac{384}{416}$ & $\frac{8325.12}{9018.88}$ & $\frac{8229.54}{7838.16}$ & $1 \frac{95.59}{180.72}$ & $\frac{1.16}{15.06}$ \\
\hline Wall panel & 6800 & 19.71 & $\frac{6704}{6794}$ & $\frac{132135.84}{133909.74}$ & $\frac{115073.28}{113776.61}$ & $\frac{17062.56}{20133.13}$ & $\frac{14.8}{17.7}$ \\
\hline Total & 7630 & - & $\frac{7486}{7616}$ & $\frac{152254.76}{154958.48}$ & $\frac{134045.92}{154958.48}$ & $\frac{18208.85}{22686.40}$ & $\frac{13.58}{17.50}$ \\
\hline
\end{tabular}

The information presented above proves economic feasibility of implementing the suggested system of factory quality control. The income obtained from products sales of the factory under study was increased by more than $20 \%$, both due to revenue growth and reduction of construction costs. It has positive effect on the indicator of production profitability which increases by $3.92 \%$.

\section{Conclusion}

The objective of integral reliability assessment of precast RC structures using probabilistic calculation methods implemented in software system was solved as a result of the conducted study. Further, methodology of automated shift-based quality control of precast $\mathrm{RC}$ structures was developed on its basis with the account of the variability of processdependent parameters. Thus, the aim of the study was accomplished. Practical approval was conducted and economic efficiency of the suggested automated quality control of precast RC structures was proved.

Conducting shift-based non-destructive quality control of structures allows reducing the number of expensive full-scale tests up to 10 times. It makes possible to reduce production costs and, therefore, provides growth of income for construction industry enterprises and, finally, will result in increasing performance ratio. Suggested control method is crucial for construction industry enterprises as it finally provides reduction of construction products cost along the whole process chain.

Further research in this direction will enable finding out the reserves for materials consumption reduction and solving production tasks on structural optimization using probabilistic methods on the basis of various models. This will contribute to developing the basis of automated control systems of the whole process procedure. 


\section{References}

1. V.D. Raizer, Teorija nadezhnosti sooruzhenij [Theory of structural safety] (Association of Civil Engineering Universities, Moscow, 2010) (in Russian)

2. A.G. Tamrazjan, I.V. Dudina, Zhilishhnoe stroitel'stvo [Housing Construction] 3, 8-10 (2001) (in Russian)

3. A.G. Tamrazjan, Vestnik MGSU 10, 109-115 (2012) (in Russian)

4. O.G. Kumpyak, Z.R. Galyautdinov, O.R. Pakhmurin, Vestnik of TSUAB 3, 88-95 (2014) (in Russian)

5. A.V. Filatov, European science 9(10), 28-29 (2015) (in Russian)

6. I.A. Rubaratuka, Journal of Engineering and Technology 2(1), 46-52 (2008)

7. E.I.G. Abdelouafi, K. Benaissa, K.Abdellatif, Procedia Engineering 114, 650-657 (2015)

8. GOST 8829-94. Izdelija stroitel'nye zhelezobetonnye i betonnye zavodskogo izgotovlenija. Metody ispytanij nagruzheniem. Pravila ocenki prochnosti, zhestkosti i treshhinostojkosti [Reinforced concrete and prefabricated concrete building products. Loading test methods. Assesment of strength, rigidity and crack resistance] (Izdatel'stvo standartov, Moscow, 1994) (in Russian)

9. V.V. Sudakov, Kontrol' kachestva i nadezhnost' zhelezobetonnyh konstrukcij [Quality control and reliability of reinforced concrete structures] (Strojizdat, Leningrad, 1988) (in Russian)

10. E.A. Sekhniashvili, Integral'naja ocenka kachestva $i$ nadezhnosti predvaritel'no naprjazhennyh konstrukcij [Integral assessment of quality and reliability of prestressed structures] (Nauka, Moscow, 1988) (in Russian)

11. Yu.A. Samarin, Stroitel'naja industrija $v$ energetike [Building industry in power engineering] 3, 2-60 (Informenergo, Moscow, 1989) (in Russian)

12. G.V. Slyusarev, News of higher educational institutions. Construction 5-6, 122-125 (1995) (in Russian)

13. V.I. Korobko, A.V. Korobko, Kontrol' kachestva stroitel'nyh konstrukcij: Vibroakusticheskie tehnologii [Quality control of building structures: Vibroacoustic technologies] (Association of Civil Engineering Universities, Moscow, 2003) (in Russian)

14. G.V. Kovalenko, S.A. Zherdeva, I.V. Dudina, Systems. Methods. Technologies 3, 161-167 (2014) (in Russian)

15. I.V. Dudina, E.V. Nester, Systems. Methods. Technologies 9, 113-118 (2011) (in Russian)

16. L.A. Kaverzina, V.A. Kaverzin, Vnutrifirmennoe planirovanie dejatel'nosti stroitel'nogo predprijatija: mehanizm realizacii, vlijanie na jeffektivnost' funkcionirovanija [Corporate planning in construction company: implementation arrangements, influence on efficiency] (LAP Lambert Academic Publishing, 2011) (in Russian)

17. G.V. Kovalenko, V.A. Ljublinskij, I.V. Dudina, S.A. Zherdeva, E.V. Nester, Application for an invention no. 2015128114, 2 (Rospatent, Moscow, 2017) (in Russian)

18. G.V. Kovalenko, I.V. Dudina, E.V. Nester, European Science and Technology: Materials of the International Research and Practice Conference (Wiesbaden, Germany, January 31, 2012)

19. O.A. Kalash, Determinirovannaja i verojatnostnaja model' naprjazhennodeformirovannogo sostojanija zhelezobetonnyh ferm $s$ uchetom fizicheskoj nelinejnosti [Deterministic and probabilistic models of stress-strain state in reinforced 
concrete trusses with regard to physical nonlinearity], PhD thesis abstract, Bratsk State University, 2009 (in Russian)

20. M.B. Krakovskiy, Beton i zhelezobeton [Concrete and Reinforced Concrete] 5, 9-11 (1997) (in Russian)

21. G. Spaethe, Die Sicherheit tragender Baukonstruktionen (Springer-Verlag Wien, New York, 1992)

22. V.P. Chirkov, Prikladnye metody teorii nadezhnosti $v$ raschetah stroitel'nyh konstrukcij [Applied methods of reliability theory in structural analysis] (Marshrut, Moscow, 2006) (in Russian)

23. G. Augusti, A. Baratta, F. Casciati, Verojatnostnye modeli $v$ stroitel'nom proektirovanii [Probabilistic Methods in Structural Engineering] (Strojizdat, Moscow, 1988) (in Russian)

24. L. Hasofer, J. of the Engineering Mech. 100, 111-121 (1974)

25. O. Ditlevsen, J. of Struct. Engineering 113(1), 38-49 (ASCE, 1988)

26. F. Liang, L. Chu, R. J. Carroll, Advanced Markov chain Monte Carlo methods (Wiley, 2010)

27. J. Voss, An Introduction to Statistical Computing: a simulation-based approach (Wiley, 2013)

28. V.S. Plevkov, I.V. Baldin, S.V. Baldin, A.G. Laskovenko, G.A. Laskovenko, Sovremennye problemy rascheta zhelezobetonnyh konstrukcij, zdanij i sooruzhenij na avarijnye vozdejstvija [Modern calculation problems of reinforced concrete structures exposed to accidental impacts], 323-328 (MGSU, Moscow, 2016) (in Russian) 